\title{
RETHINKING THE JURISPRUDENCE OF CYBERSPACE. REED, C.; MURRAY, A.
}

by

DOMINIKA GALAJDOVÁ*

Reed, C.; Murray, A. (2018) Rethinking the Jurisprudence of Cyberspace. Cheltenham: Edward Elgar Publishing, 235 p.

Rethinking the Jurisprudence of Cyberspace is the joint work of Chris Reed and Andrew Murray which follows their previous contribution on the topic of legal theory and cyberspace. ${ }^{1}$ The book aims to provide an answer to one of the most fundamental questions which law is applicable in cyberspace? The authors have considered through the whole book the elementary ideas of jurisprudence in the online environment, such as authority, legitimacy and rule of law. The book reflects on the recognised previous work on this topic by different commentators (Lessig, Johnson and Post, Reidenbers) and continues with its own concluding remarks and considerations.

The book is divided into three parts which contain together 8 chapters. Each part also includes a semi-conclusion at the end, which is helpful and practical for readers. The first part is focused on the authority in cyberspace and discusses various lawmakers, their role and rules in cyberspace. The second part provides a complex analysis of how rules actually operate in the online environment. The last part reflects the conclusion of previous parts as well as providing an answer to the question of how subjects should

dominika.galajdova@mail.muni.cz, Ph.D. student at the Institute of Law and Technology on Masaryk University, Brno, the Czech Republic.

1 Reed, C. (2012) Making Laws for Cyberspace. Oxford: Oxford University Press; Murray, A. (2007) The Regulation of Cyberspace: Control in the Online Environment. Abingdon: Routledge; Murray, A. (2011) Nodes and Gravity in Virtual Space. Legisprudence, 5 (2), pp. 195-221; Murray, A. (2008) Symbiotic Regulation. John Marshall Journal of Computer E Information Law, 26 (2), pp. 207-228. 
respond if they wish to achieve the legitimate authority and rule of law in cyberspace.

Part I "Law and authority in cyberspace" is divided into three chapters which are devoted to the three main cyberspace rule makers: i) states, ii) transnational and technical rule makers, iii) communities or private lawmakers. All three chapters describe the source of authority of each aforementioned lawmaker and explore the limits of their authority and its application in cyberspace. Further considerations provide a detailed description of rulemaking of each subject as well as how they communicate these rules to the community and individual cyberspace actors. The authors have built their argumentation upon the distinguished works of Johnson and Post $^{2}$, and Goldsmith ${ }^{3}$ as well as on the relevant case law ${ }^{4}$ in considering the state as lawmaker. The first chapter describes the fundamental legal theory for the question of the authority of the state. ${ }^{5}$ The authors concluded that the authority of the state has been originally viewed from the perspective of its authority within its own territory; however, this approach is very simplistic and undermines the role of the legitimating community which is in the case of cyberspace significant. In the following chapter, the main focus is on non-state rule makers which are demonstrated by example of subjects having control over technical infrastructure (e.g. Internet Society, Internet Engineering Task Force, Internet Architecture Board, ICANN, etc.). The analysis of various theories (e.g. strict constitutional theory, constitutional pluralism, solid/liquid approach) related to legal pluralism in regards to a transnational non-government system is also included. ${ }^{6}$ Lastly, the community and its role in cyberspace is examined in-depth. The rule of recognition of validity of claim is stated by the authors as a principle in the online environment and helps to understand the authority of claims of different lawmakers to both the community and individual cyberspace actors. ${ }^{7}$ This part concludes that in the case of the online environment, authority of different lawmakers and its rules can be appropriately assessed only for the individual rules of law

Johnson, D. R.; Post, D. G. (1996) Law and Borders - The Rise of Law in Cyberspace. Stanford Law Review, 48 (5), pp. 1367-1402.

Goldsmith, J. (1998) Against Cyberanarchy. Chicago Law Review, 65 (4), pp. 1199-1250.

4 See pp. 10-11 of the book.

5 See pp. 14-18 of the book.

6 See pp. 27-37 of the book.

7 See pp. 63-66 of the book. 
not the law as a whole system. Furthermore, it is pointed out that the role of the community increases in cyberspace.

Part II moves forward and focuses on how rules actually work in the online environment. The fourth chapter starts at the very bottom and describes law as a coercive system where the author pointed out the actual control of human behaviour by law. The authors also involved studies of behavioural scientists to support their arguments which provides added value from interdisciplinary perspectives. ${ }^{8}$ The subsection 4.2 enters into the considerations of the impact of technology on the behaviour of cyber actors and its potential for application of law. This subsection engages with the familiar work of Lawrence Lessig ${ }^{9}$ and confronts his work. The authors highlighted that there are two flaws in Lessig's thesis: i) misunderstanding of the ways in which the modalities of regulation interact; ii) belief in perfection of control which is possible via code. ${ }^{10}$ Following this, an examination of these observations is conducted. The interaction between modalities of regulation is in Lessig's view a linear one, while the authors suggested that there is a continuous communication and interaction between them as well as there is a huge impact of the mass of cyberspace users. $^{11}$ The perfection of code's control is also examined and refused mainly based on two reasons: i) the nature of design-based controls to regulate without discourse and in an ex-ante fashion (presumption that the individual has no social choice to act differently in an environment with design-based controls); ii) the plasticity of code (that code can be rewritten or redesigned). These assumptions are also complemented by other arguments such as the importance and impact of social norms and the market on the regulation of cyberspace and on code. ${ }^{12}$ The weakness of code control is demonstrated by several examples (e.g. spam filters, digital rights management, or change of policy of Facebook). ${ }^{13}$ This in-depth evaluation is very important since Lessig's work proves to be very popular in the academic sphere as well as with the general public where some misunderstanding and misinterpretation of Lessig's thesis occurs.

See pp. 83-84 of the book.

9 Lessig, L. (1999) Code and Other Laws of Cyberspace. New York: Basic Books; Lessig, L. (2006) Code Version 2.0. New York: Basic Books.

10 See p. 88 of the book.

11 See p. 91 of the book.

12 See p. 97 of the book.

13 See pp. 94-99 of the book. 
Following the conclusion of previous chapter, the authors have entered into a discussion of the different norms of cyberspace in the fifth chapter. The introduction is devoted to the three theories of social normative compliance, namely rational choice theory, evolutionary theory and social rationality theory. The discussion brings together observations about the community and its role in cyberspace from the previous part with a conclusion that the prevailing importance of social rationality is due to the nature of online communities. ${ }^{14}$ Another subsection then describes different sources of norms in the online environment which are identified as norms of service providers, norms based on user interactions and technical norms. In the conclusion to this chapter, the competition between different norms of cyberspace is decided based on authority of different claims and thus the various communities obey their norms via acceptance of such authority. Furthermore, the understanding of such competition of different norms in cyberspace can provide lawmakers with helpful guidance within the lawmaking process to follow the established norms of cyberspace.

The last chapter of Part II is focused on a broader perspective covering the topic of regulation and governance in cyberspace. The discussion starts with an understanding of the relationship between technology, regulation and governance while providing a description of Actor-Network Theory and Science and Technology Studies. ${ }^{15}$ In the following, the authors have opened up debates on the fundamental streams regarding governance of cyberspace, cyberlibertarianism and cyberpaternalism. ${ }^{16}$ The authors reminded us of the noted works of John Perry Barlow ${ }^{17}$ and Johnson and Post ${ }^{18}$, and confronts it with the Cyberpaternalist School ${ }^{19}$ and concept of a "Lex Informatica ${ }^{\prime 2}$, which argues that there are several new models and sources of rules in the online environment. The debate is completed by Murray's

\footnotetext{
14 See p. 107 of the book.

15 See pp. 141-144 of the book.

16 See pp. 144-152 of the book..

17 Barlow, J. P. (1996) Declaration of Independence of Cyberspace. [online] Davos: EFF. Available from: https://www.eff.org/cyberspace-independence [Accessed 5 February 2019].

18 See footnote 2.

19 Winner, L. (1997) Cyberlibertarian Myths and the Prospect for Community. [online] Troy: RPI. Available from: http://homepages.rpi.edu/ winner/cyberlib2.html [Accessed 5 February 2019]; Jones, R. (1996) Critique of Barlow's "A Declaration of Independence of Cyberspace". Extropy: Journal of Transhumanist Solution, 17 (8).

20 Reidenbers, J. (1998) Lex Informatica: The Formation of Information Policy Rules Through Technology. Texas Law Review, 76 (3), pp. 553-593.
} 
concept of the Network Communitarianism and Symbiotic Regulation which leans towards soft determinism that sees technology as an enabling rather than a constraining force. ${ }^{21}$ Part II is closed by concluding remarks on the role of various platforms and gatekeepers in cyberspace. The content of the longest part of the book is very detailed and complex and so, gives readers great insight into the fundamental ideas in jurisprudence as well as famous concepts and considerations in regards to cyberspace. This part forms the core of the book. The theoretical parts are also accompanied by various examples and case law which help to better understand the theoretical background.

The last part of the book is focused on the question of what lawmakers need to do to establish legitimacy of their claims and to achieve the rule of law in the online environment. The seventh chapter concentrates on the issue of legitimacy which in the authors' view cannot fully secure authority in the online environment. However, the rule of legitimacy as itself has the same importance as in the offline environment. ${ }^{22}$ The authors pointed out that individual claims can be either legitimate or illegitimate and the level of their legitimacy can vary. ${ }^{23}$ The authors viewed the legitimacy of an individual claim from the Paiement perspective $^{24}$ to consider the input, throughput and output aspects of lawmaking when reflecting on the specific nature of cyberspace. The authors concluded that output aspects which are based on the quality of the norms are the most important in terms of legitimacy in cyberspace. This is the very different between online and offline environments where the legitimacy is primarily derived from constitutions.

In further text, the authors have identified that three factors are important for obedience or disobedience of the law's authority claim: i) the extent to which the law claim is perceived to being addressed to the cyberspace user; ii) how far the law claim is compatible with the rest of the environment in which the cyberspace user acts; iii) the observed fairness and justice of the claim. The first factor is demonstrated by the case C- $101 / 01^{25}$ in connection with the failure to communicate law claims and

${ }^{21}$ See p. 155 of the book.

22 See p. 173 of the book.

23 See p. 174 of the book.

24 Paiement, P. (2013) Paradox and Legitimacy in Transnational Legal Pluralism. Transnational Legal Theory, 4 (2), pp. 197-226.

25 Judgement of 6 November 2003, Bodil Lindqvist, C-101/01, EU:C:2003:596. 
an analogy with reception theory is highlighted. The crucial element is though communication of such claims for their legitimacy. The compatibility of law claims with the online environment is viewed as the difference between behaviour required and imposed by law and actual reality of the environment in which the law applies. ${ }^{26}$ It is concluded that more radical change of behaviours set by laws usually requires stronger justification of their legitimacy. One of the challenges for lawmakers in such a context is to make laws for cyberspace that are congruent with the norms applied to similar physical world activities when the principle of technological neutrality and principle of equivalence are highlighted. Lastly, the fairness and justice of claims are described. The authors addressed the challenge that lawmakers faced in cyberspace as balancing the interest and rights of different groups, especially conflict between the minority and majority. ${ }^{27}$ The suggestion is that a lawmaker might prove the legitimacy of a claim if a lawmaker demonstrates and explains how the balance of such rights and interests was evaluated.

The last chapter of the book deals with the concept of the rule of law in cyberspace. The beginning of the chapter provides the reader with a brief overview of various concepts of the rule of law from Fuller ${ }^{28}$ to Bingham ${ }^{29}$ or Waldron" ${ }^{30}$. The authors have produced their own version, the "laundry list" of the rule of law which is examined in the further text. This "laundry list" consists of six principles: i) law must be set forth in advance (be prospective); ii) law must be made public; iii) law must be general; iv) law must be clear; v) law must be stable and certain; vi) law must be applied to everyone according to its terms. ${ }^{31}$ In the following text, the authors examined all of aforementioned principles and whether they are established in cyberspace. The text demonstrates several obstacles and difficulties (e.g. the amount of laws, cost of digitisation of information and clarity of laws, to meet these principles in the online environment). In conclusion, the rule of law can be viewed from the perspective of acceptance by cyberspace users rather than application of different legal systems.

\footnotetext{
26 See pp. 183-194 of the book.

See pp. 195-197 of the book.

28 Fuller, L. L. (1969) Morality of Law. New Haven: Yale University Press.

29 Bingham, T. (2010) The Rule of Law. London: Penguin.

${ }^{30}$ Waldron, J. (2011) The Rule of Law and the Importance of Procedure. In: James E. Fleming (ed.). Getting to the Rule of Law: NOMOS L. New York: NYU Press, pp. 3-31.

31 See p. 206 of the book.
} 
The book as a whole presents a comprehensive discussion of the legal theory as well as findings in regards to cyberspace. While the text leans significantly on a body of literature on the topic, there are interesting and novel conclusions made by the authors which add value for this book. The authors viewed the regulation of cyberspace from perspective of competing rules and authorities. The book emphasises the importance of social norms in cyberspace and considers the ability of an authority to impact those norms. The authors considered that any significant deviation from social norms would impair authority and legitimacy of law claims of rule makers. The key takeaways from the book are the question of sources of authority (states vs. communities), the identification of jurisprudence, the role of social and other norms and their competition with the authority of law, and the necessity to establish legitimacy of law claims of authority. Also, a significant advantage of the book is definitely the language which is very understandable and clear for readers. The book can then serve as a fundamental introduction to the jurisprudence of cyberspace as well as a new perspective on this challenging topic. The book advances the discussion on various aspects of cyberspace and its regulation and provides some conclusions in this area, however, unresolved questions remain. The book therefore can be recommended to the great spectrum of readers with interest in fundamental questions related to the regulation of cyberspace.

\section{LIST OF REFERENCES}

[1] Barlow, J. P. (1996) Declaration of Independence of Cyberspace. [online] Davos: EFF. Available from: https://www.eff.org/cyberspace-independence [Accessed 5February 2019].

[2] Bingham, T. (2010) The Rule of Law. London: Penguin.

[3] Fuller, L. L. (1969) Morality of Law. New Haven: Yale University Press.

[4] Goldsmith, J. (1998) Against Cyberanarchy. Chicago Law Review, 65 (4).

[5] Johnson, D. R.; Post, D. G. (1996) Law and Borders - The Rise of Law in Cyberspace. Stanford Law Review, 48 (5).

[6] Jones, R. (1996) Critique of Barlow's "A Declaration of Independence of Cyberspace". Extropy: Journal of Transhumanist Solution, 17 (8).

[7] Judgement of 6 November 2003, Bodil Lindqvist, C-101/01, EU:C:2003:596.

[8] Lessig, L. (1999) Code and Other Laws of Cyberspace. New York: Basic Books.

[9] Lessig, L. (2006) Code Version 2.0. New York: Basic Books. 
[10] Murray, A. (2007) The Regulation of Cyberspace: Control in the Online Environment. Abingdon: Routledge.

[11] Murray, A. (2008) Symbiotic Regulation. John Marshall Journal of Computer E Information Law, 26 (2).

[12] Murray, A. (2011) Nodes and Gravity in Virtual Space. Legisprudence, 5 (2).

[13] Paiement, P. (2013) Paradox and Legitimacy in Transnational Legal Pluralism. Transnational Legal Theory, 4 (2).

[14] Reed, C. (2012) Making Laws for Cyberspace. Oxford: Oxford University Press.

[15] Reidenbers, J. (1998) Lex Informatica: The Formation of Information Policy Rules Through Technology. Texas Law Review, 76 (3).

[16] Waldron, J. (2011) The Rule of Law and the Importance of Procedure. In: James E. Fleming (ed.). Getting to the Rule of Law: NOMOS L. New York: NYU Press.

[17] Winner, L. (1997) Cyberlibertarian Myths and the Prospect for Community. [online] Troy: RPI. Available from: http://homepages.rpi.edu/ winner/cyberlib2.html [Accessed 5 February 2019]. 